\title{
DEVELOPMENT OF HPLC METHOD FOR QUANTITATIVE DETERMINATION OF EPIMIDIN - NEW PERSPECTIVE APhI WITH ANTICONVULSIVE ACTIVITY
}

\author{
H. Severina, I. Bezruk, L. Ivanauskas, V. Georgiyants
}

\begin{abstract}
Мета. Розробка оптимальної, високоточної та відтворюваної методики кількісного визначення основної речовини в субстаниї Eniмiдину - 1-(4-methoxyphenyl)-5-[2-[4-(4-methoxyphenyl)piperazin-1-yl]-2-oxoethyl]pyrazolo[3,4-d]pyrimidin-4-опе методом високоефективної рідинної хроматографіï.

Матеріали і методи. Високоефективну рідинну хроматографію (ВЕРХ) проведено використовуючи систему ShimadzuNexeraX2 LC-30AD (Shimadzu, Японія), оснащений діодним матричним детектором SPDM20A (DAD). Колонка ACE C18, розміром 250×4,6 мм, фірми YMC з передколонкою, з розміром часток 5 мкм, заповнену силікагелем октилсилільним для хроматографії Р. В роботі використовувалися ачетонітрил та трифтороитову кислоту класу HPLC (Sigma-AldrichGmbH, Швейцарія), інші хімічні речовини та розчинники були аналітичного сорту. У дослідженні використовували аналітичний посуд класу $A$, щзо відповідаює вимогам ДФУ.

Результати. Встановлено наступні оптимальні умови хроматографічного розподілу: колонка С18

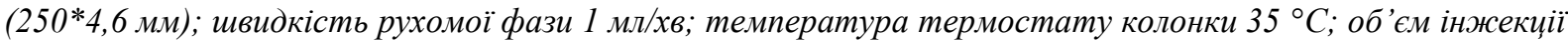
10 мкл; рухома фаза А - 0,1\% трифтороитова кислота; рухома фаза Б - ацетонітрил Р; довжина хвилі детектування 270 нм, час утримування досліджуваної сполуки становить 7.22 хв. Продуктивність колонки була визначена для ї̈ основних показників, таких як кількість теоретичних тарілок (більше 25410) i коефіцієнт симетрії (близько 1,00). Методику було апробовано на вплив різних факторів, таких як, швидкість потоку, склад рухомої фази та температура термостату колонки. Встановлено, щзо вплив цих факторів є незначущчим та не впливає на результати, отримані за цією методикою. Методика була валідована згідно з рекомендаціями ДФУ за параметрами специффічністі, лінійністі, правильністі, прецизійністі, робасністі (стабільність).

Висновки. Вперше розроблена високоточна та відтворювана методика кількісного визначення основноі речовини у субстанції Епімідину з протисудомною активністю методом високоефективної рідинноі хроматографії. Стандартизовано умови проведення хроматографічного аналізу (ВЕРХ). Встановлено вимоги до тесту «Перевірка придатності хроматографічної системи». Статистична обробка результатів експерименту свідчить, шо відносна невизначеність середнього результату знаходиться у допустимих межах. Коректність методики підтверджено валідачійними дослідженнями. Розроблена методика буде використана для фармачевтичної розробки та стандартизачиї лікарської форми
\end{abstract} Ключові слова: Епімідин, піразолопіримідин, антиконвульсант, кількісне визначення, ВЕРX

\section{Introduction}

In the treatment of epilepsy and other pathological conditions accompanied by convulsions, the use of drugs remains the leading method of treatment. Despite the wide choice of antiepileptic drugs (AEDs) with different mechanisms of action, including prolonged, satisfactory control of seizures is achieved in only $65-70 \%$ of patients [1]. It is the development of refractory forms of epilepsy [2], the need for simultaneous administration of several AEDs, the lack of drugs that would meet the criteria of high efficacy with a favourable safety profile, prompts the search for anticonvulsants among new classes of compounds. In the context of the above problem, a promising API with anticonvulsant activity was synthesized - (4-methoxyphenyl)-5-[2-[4-(4-methoxyphenyl) piperazin-1-yl]-2-oxo-ethyl]pyrazolo[3,4-d]pyrimidin-4one, which gave the code name "Epimidin" (Fig. 1) [3].

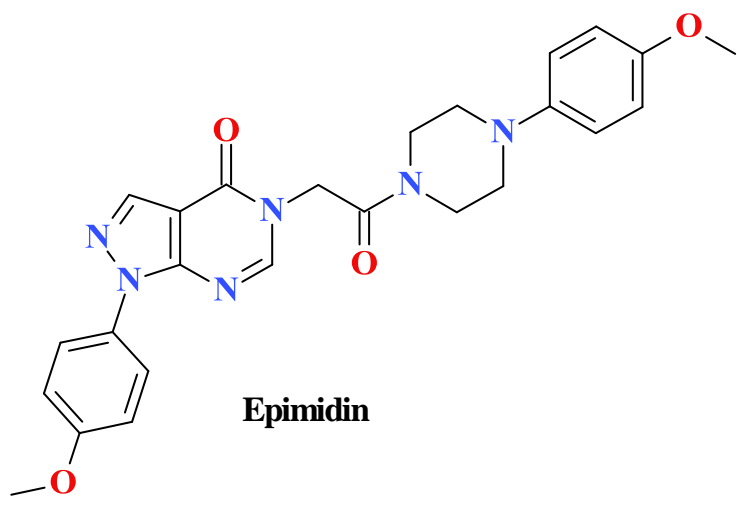

Fig. 1. The promising anticonvulsant -

(4-methoxyphenyl)-5-[2-[4-(4-methoxyphenyl)piperazin-1-yl]-2-oxo-ethyl]pyrazolo[3,4-d]pyrimidin-4one (Epimidin) 
The strong anticonvulsant activity of Epimidin has been proven in various models of seizures: on the pentylenetetrazole (PTZ) model at a dose of $200 \mathrm{mg} / \mathrm{kg}$ exceeds the effect of the comparison drug sodium valprotate at a dose of $300 \mathrm{mg} / \mathrm{kg}[3,4]$, a pronounced effect on seizures caused by caffeine and picrotoxin, moderate on strychnine convulsions [5]; high efficiency under conditions of experimental chronic epileptogenesis model of PTZ-kindling; on the model of the maximum electroshock shows moderate activity. Wide range of effective anticonvulsant doses, favourable concomitant pharmacological profile: weak sedative and anxiolytic effect without muscle relaxant properties, positive effect on cognitive functions, no effect on depressive behaviour, no antihypoxic properties [5] and belonging to the $\mathrm{V}$ class of toxicity justifies the need for further study of Epimidin as a potential API.

The introduction of a new API or drug in medical practice is impossible without the development of methods for its analysis [6, 7]. A necessary and important stage of implementation is the development of an effective, unified, optimal, high-precision, reproducible and rapid method of quantitative determination of the active substance in the substance. To quantify pyrimidine and pyrazolopyrimidine derivatives, scientists use a variety of physicochemical methods, including ion chromatography [8], thin-layer chromatography and HPLC [9, 10], gas chromatography [11], polarography [12], spectrofluorimetry [13], etc. The subjects of the study were substances, various dosage forms and body fluids [14, 15]. Highperformance liquid chromatography remains a priority for all subjects. The use of HPLC for the identification, separation and quantification of the hypnotic drug zaleplon - 3-(3-cyanopyrazolo[1,5-a]pyrimidin-7-yl)-Nethylacetanilide has been widely demonstrated. Use of different mobile phases, such as methanol - water [13], acetonitrile - deionized water [9], ammonium formate buffer - acetornitrile [14], $5 \%$ acetonitrile, $95 \%$ formic acid $0.1 \%$ to a ratio of 80-20\% [15], methanol - ammonium acetate buffer [16], the use of UV and MS detection allowed to determine zaleplon in different dosage forms and in blood plasma. It is due to the wide possibilities of HPLC method that it was chosen to quantify Epimidin.

The aim of the research. Development of a method for the quantitative determination of Epimidin in a substance using the method of high performance liquid chromatography.

\section{Planning (methodology) of research}

The State Pharmacopoeia of Ukraine recommends the use of direct objective methods for the quantification of APIs, such as, for example, titrimetric methods. Previously, a method for the quantitative determination of Epimidin by the method of nitrogen determination in organic compounds after mineralization with sulfuric acid was developed, which is described in the general monograph of SPhU 2.5.9 [17]. But the developed method is unacceptable for dosage forms, as excipients will interfere with the definition. Therefore, for subsequent pharmaceutical development in the dosage form, it was proposed to determine Epimidin using the method of high performance liquid chromatography. The presented study included the following stages: selection of optimal chromatography conditions and development of a technique based on high performance liquid chromatography, conducting an experiment to assess the suitability of the chromatographic system and predict the uncertainty of the analysis results, and validation according to SPhU requirements.

\section{Materials and methods}

Liquid chromatography separation was performed using a Shimadzu Nexera X2 LC-30AD HPLC system (Shimadzu, Japan) composed of a quaternary pump, an on-line degasser, a column temperature controller, the SIL-30AC autosampler (Shimadzu, Japan); the CTO20AC thermostat (Shimadzu, Japan) as well as the SPDM20A diode array detector (DAD). Another instruments such as Ultrasonic Cleaner Set for ultra-sonication using (Wise Clean WUC-A06H, Witeg Labortechnik GmbH, Germany), Libra UniBloc AUW120D (Shimadzu Analytical Scale, Japan); class A analytical vassals that meets requirements of the $\mathrm{SPhU}(\mathrm{SPhU}, 2015)$ were used in the investigation. HPLC grade acetonitrile (SigmaAldrich $\mathrm{GmbH}$, Switzerland) were used in the analysis work. HPLC grade water was obtained from a water purifying system (Millipore, Bedford, MA, USA). Other chemicals and solvents were of analytical grade.

Quantification of Epimidin by HPLC was performed on an ACE C18 column (250x4.6 mm, particle size $5 \mu \mathrm{m}$ ) with a pre-column filled with octylsilyl silica gel for chromatography $\mathrm{P}$, for which the conditions of suitability of the chromatographic system are met. A binary system of mobile phase solvents was used: solvent A ( $0.1 \%$ trifluoroacetic acid) and solvent B (acetonitrile $\mathrm{P})$. The following profile of the linear gradient elution was used: $0-9$ min $65 \rightarrow 50 \% \mathrm{~A}, 35 \rightarrow 50 \% \mathrm{~B}$; 9-11 min $50 \%$ A, $50 \%$ B; 11-12 min $50 \rightarrow 65 \%$ A, $50 \rightarrow 35 \%$ B; $12-15 \min 65 \% \mathrm{~A}, 35 \% \mathrm{~B}$. The flow rate was maintained at $1 \mathrm{ml} / \mathrm{min}$ with UV detection at $270 \mathrm{~nm}$. The sample injection volume was $10 \mu \mathrm{l}$ and the column temperature was maintained at $35^{\circ} \mathrm{C}$.

Test solution. $60 \mathrm{mg}$ (precisely weighed) of the substance KS 78553 is placed in a volumetric flask with a capacity of $250.0 \mathrm{ml}$, add $30.0 \mathrm{ml}$ of DMSO, treated in an ultrasonic bath for 15 minutes before dissolution, bring to the mark with methanol P. Take $20.0 \mathrm{ml}$ of the resulting solution and make up to volume $50.0 \mathrm{ml}$ with methanol P. Filter through a membrane filter with a pore diameter of not more than $0.45 \mu \mathrm{m}$. The freshly prepared solution is used.

Comparison solution. $60 \mathrm{mg}$ (precisely weighed) of the standard substance KS 78553 is placed in a volumetric flask with a capacity of $250.0 \mathrm{ml}$, add $30.0 \mathrm{ml}$ of DMSO, treated in an ultrasonic bath for 15 minutes before dissolution, bring to the mark methanol P. Take 20.0 $\mathrm{ml}$ of the resulting solution and make up to volume. 50.0 $\mathrm{ml}$ of methanol P. Filter through a membrane filter with a pore diameter of not more than $0.45 \mu \mathrm{m}$. The solution is used freshly prepared.

\section{Result}

Under these conditions, the release time of the main peak of Epimidin was 7.22 minutes. Fig. 2 shows the chromatogram of the test solution. 


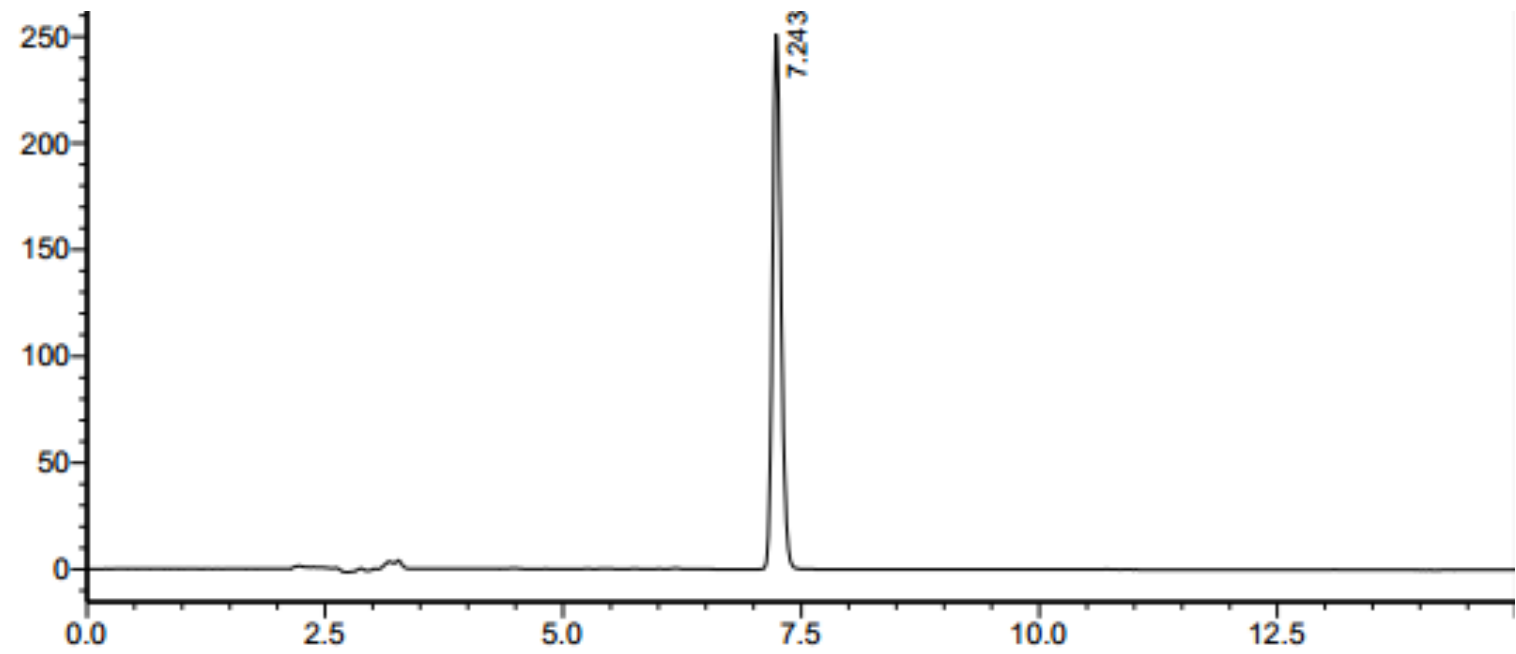

Fig. 2. Chromatogram of the tested solution of Epimidin

The chromatographic system is considered suitable if the following conditions are met for the reference solution:

- the efficiency of the chromatographic column, calculated at the peak of the basic substance, must be at least 3000 theoretical plates;
- the peak symmetry coefficient should be in the range from 0.8 to 1.5 ;

- the relative standard deviation for peak areas should not exceed $1.0 \%$, calculated from 5 injections. Quantitative characteristics of the suitability of the chromatographic system of the Epimidin comparison solution are given in Table 1 .

Table 1

Characteristics of the chromatographic system for the comparison solution

\begin{tabular}{|c|c|c|c|}
\hline Substance & $\begin{array}{c}\text { Efficiency } \\
\text { (number of theoretical plates) }\end{array}$ & Symmetry factor & Relative standard deviation, \% \\
\hline Epimidin & 25410 & 1.18 & 0.06 \\
\hline
\end{tabular}

\section{Prognosis of analysis results uncertainty}

The maximum allowable total relative uncertainty of the substance analysis method $\Delta \mathrm{AS} \%$ is related to the symmetrical tolerances of the content of the analyte according to the specification (B). That is:

$$
\Delta A S \leq \frac{B_{H}-B_{L}}{2} \times 0.32 .
$$

The quantitative content of its components in the substance of Epimidin should be within $\pm 5 \%$, therefore:

$$
\Delta A S \leq \frac{95-105}{2} \times 0.32=1.6 \% .
$$

Calculation of uncertainty of sample preparation is given in Table 2.

Table 2

Calculation of sample preparation uncertainty $(\Delta \mathrm{sp})$

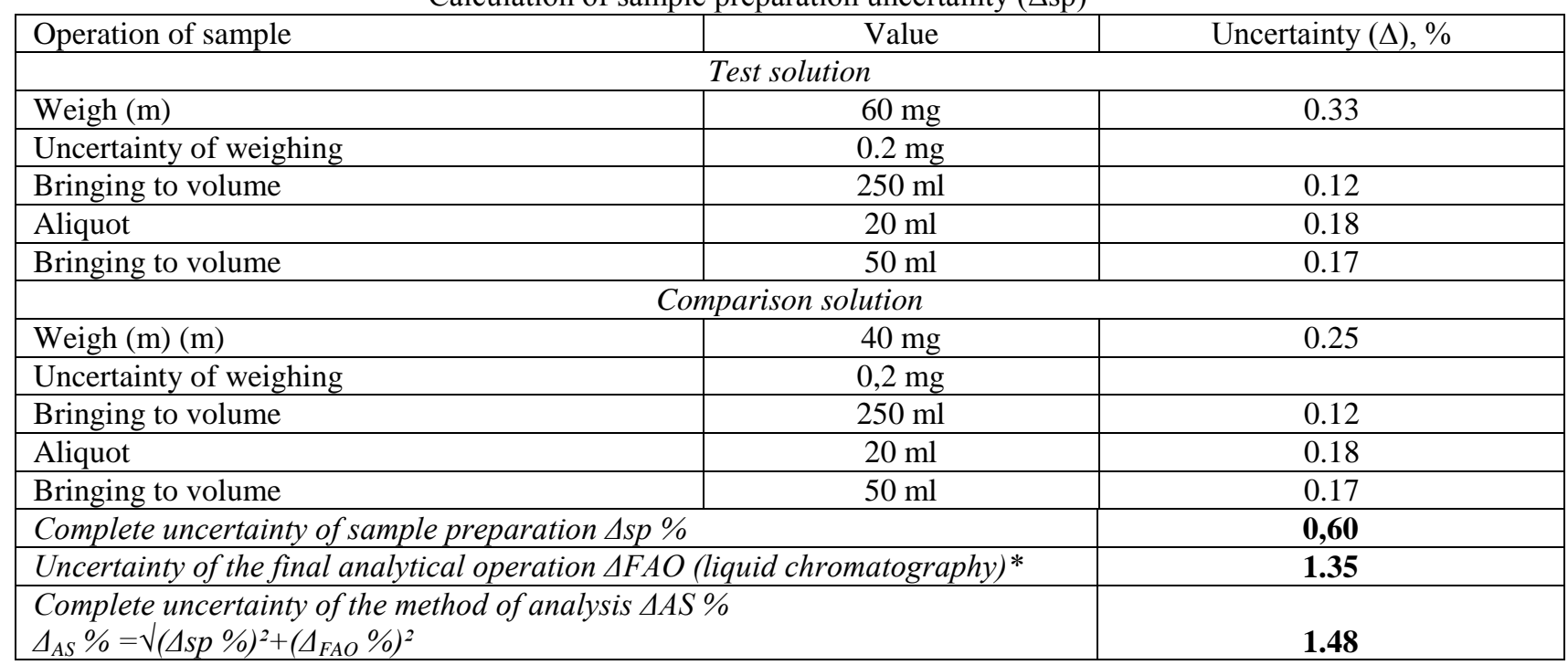


Determination of the uncertainty of the final analytical operation $\Delta_{\text {FAO }}$ is performed for the test solution and the comparison solution. When calculating confidence intervals use a one-sided Student's ratio for a probability of $95 \%$ and the corresponding number of degrees of freedom. Confidence intervals for the comparison solution and the test solution are calculated for the average of 5 results (maximum number of measurements according to the MQC of the drug).

$$
\begin{aligned}
& \Delta_{F A O}^{c m}=\frac{1}{\sqrt{5}} \times t(95 \%, n-1) \times R S D, \\
& \Delta_{F A O}^{c m}=\frac{1}{\sqrt{5}} \times t(95 \%, n-1) \times R S D .
\end{aligned}
$$

According to the requirements of the suitability of the chromatographic system of the determination method, the relative standard deviation of five parallel determinations should not exceed $1.0 \%$. At $\mathrm{n}=5$, $\mathrm{t}(95 \%$, $\mathrm{n}-1)=2.1318$ :

$$
\begin{aligned}
& \Delta_{F A O}^{c m}=\frac{1}{\sqrt{5}} \times 2,1318 \times 1,0 \%=0.9534, \\
& \Delta_{F A O}^{s m p}=\frac{1}{\sqrt{5}} \times 2.1318 \times 1.0 \%=0.9534 .
\end{aligned}
$$

Total uncertainty of the final analytical operation:

$$
\Delta_{F A O}=\sqrt{\left(\Delta_{F A O}^{s m p}\right)^{2}+\left(\Delta_{F A O}^{s m p}\right)^{2}}=1.35 \text {. }
$$

Complete uncertainty of the analysis method $\Delta_{A S} \%$ :

$$
\begin{aligned}
& \Delta_{A S}=\sqrt{\left(\Delta_{s p}\right)^{2}+\left(\Delta_{s p}\right)^{2}}=1.50 \%, \\
& \Delta_{A S}=\sqrt{\left(\Delta_{s p}\right)^{2}+\left(\Delta_{s p}\right)^{2}}=1.49 \% .
\end{aligned}
$$

\section{Validation study}

To confirm the correctness of the proposed method, validation studies were performed in accordance with the requirements of SPhU [17]. The following validation parameters were calculated: specificity, linearity, correctness, precision, robustness (stability).

Specificity. The retention times of the Epimidin peak on the chromatogram of the test solution correspond to the retention time of the Epimidin peak on the chromatogram of the reference solution - approximately 7.22 min (Fig. 2-3).

Linearity. To confirm the linearity of the method, 9 model solutions were prepared, the concentration of which varies evenly within the range of application $($ step $-5 \%)$.

$\mathrm{Xi}=\mathrm{Ci} / \mathrm{Cst} \cdot 100$ and $\mathrm{Yi}=\mathrm{Si} / \mathrm{Sst} \cdot 100($ Tables 2,3$)$.
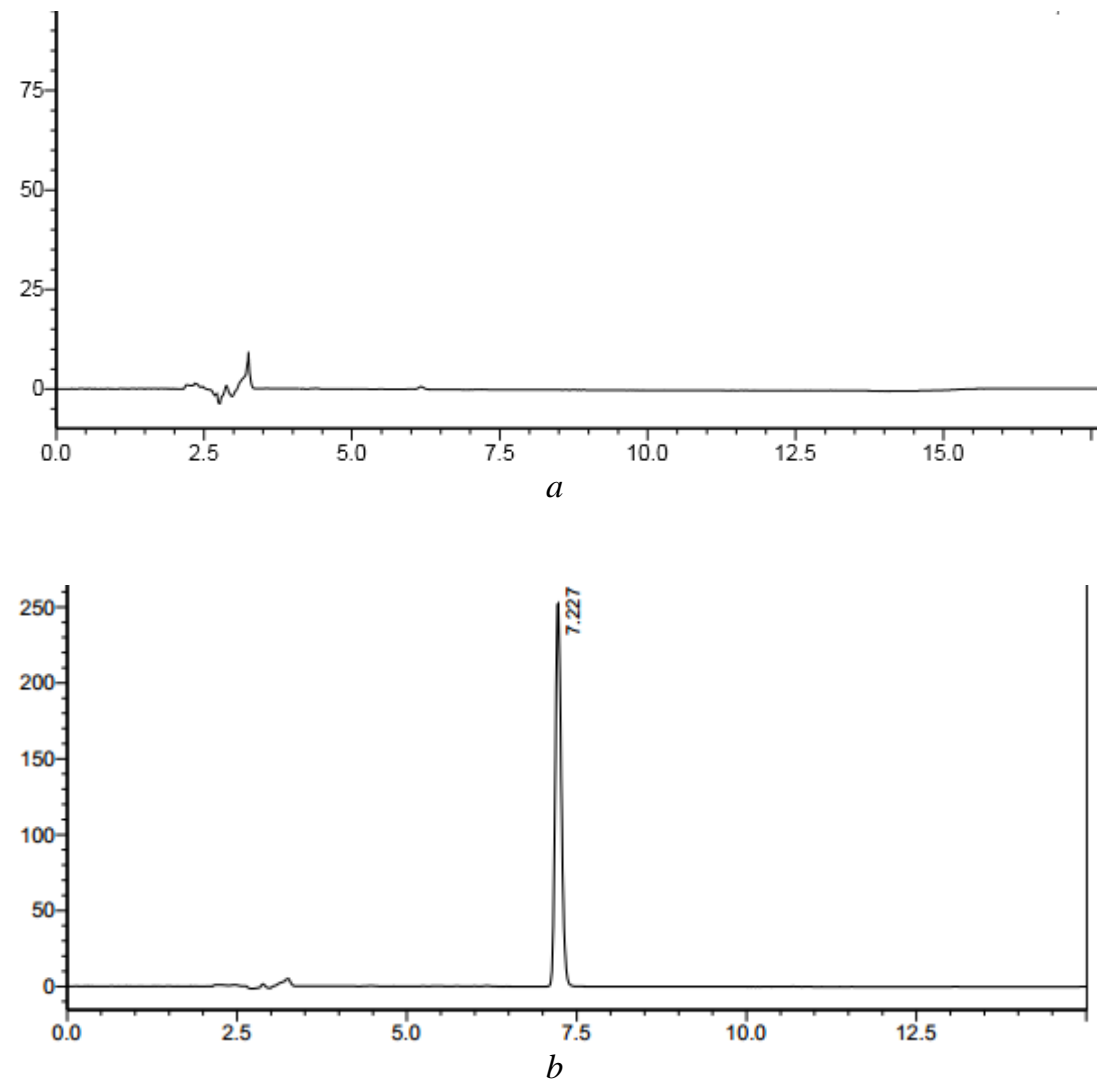

Fig. 3. The chromatograms of solutions: $a$-solvent (blank-chromatogram); $b$-comparison solution 
Calculation of linearity parameters of the method of quantitative determination of Epimidin

\begin{tabular}{|c|c|c|c|c|c|}
\hline No. & $\mathrm{C}, \%$ & $C(\mathrm{mg} / \mathrm{ml})$ & $C_{i / s t}$ & The average value of the peak area & $S_{i / s t}$ \\
\hline 1 & 80 & 0.0768 & 80.0 & 1269455 & 80.20 \\
\hline 2 & 85 & 0.0816 & 85.0 & 1348517 & 85.20 \\
\hline 3 & 90 & 0.0864 & 90.0 & 1425586 & 90.07 \\
\hline 4 & 95 & 0.0912 & 95.0 & 1508682 & 95.32 \\
\hline 5 & 100 & 0.096 & 100.0 & 1577694 & 99.68 \\
\hline 6 & 105 & 0.1008 & 105.0 & 1657269 & 104.70 \\
\hline 7 & 110 & 0.1056 & 110.0 & 1734989 & 109.61 \\
\hline 8 & 115 & 0.1104 & 115.0 & 1819394 & 114.95 \\
\hline 9 & 120 & 0.1152 & 120.0 & 1895002 & 119.72 \\
\hline Standard & 100 & 0.096 & 100.0 & 1582834 & 100,00 \\
\hline
\end{tabular}

In Fig. 4 presented a graph of the linear dependence of the analytical signal on the actual concentration of the Epimidin solution, constructed in normalized coordinates, based on the data in the Table 4.

Data of linearity verification of the method of quantitative determination of Epimidin are presented in Table 4.

Correctness. To determine the correctness within the range of use of the analytical method, 9 test solutions were prepared in compliance with all stages of the analytical method. The calculation of the parameters of correctness and the conclusion about the correctness of the method is given in Table 5 .
The correctness of the method was performed according to two criteria - practical and statistical insignificance, which were determined during experimental studies (Table 6).

Intra-laboratory precision. To determine, the results of a study of 6 tests of one sample performed by two analysts on different days during one working week using different measuring vessels were used. Determination of the parameters of intralaboratory precision are given in Table 7 , and the results of the precision assessment in Table 8.

Robustness (stability). The study of the stability of the test solution was performed after 24 hours, and the results are shown in Table 9.

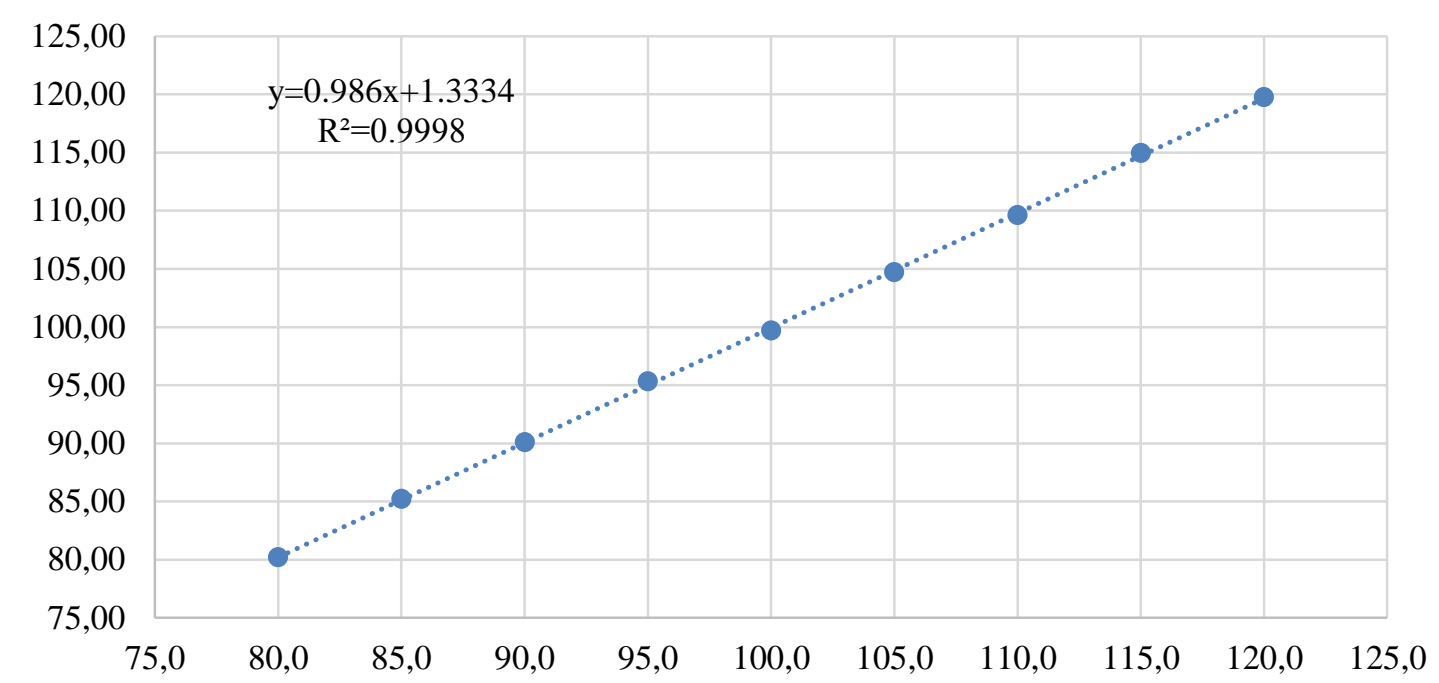

Fig. 4. Graph of the linear dependence of the analytical signal on the actual concentration of the Epimidin solution

Data of linearity verification of the method of quantitative determination of Epimidin

\begin{tabular}{|c|c|c|c|c|}
\hline № & Parameter & Requirements & The value obtained & Fulfillment of the criterion \\
\hline 1 & \begin{tabular}{l|l|l|} 
& $\mathrm{a}$ & \\
\end{tabular} & $\leq 4.8$ & 0.986 & Executed \\
\hline 2 & $\mathrm{~S}_{0}$ & $\leq 1.58$ & 0.24 & Executed \\
\hline 3 & $\mathrm{r}$ & $>0.9933$ & 0.9998 & Executed \\
\hline
\end{tabular}


Table 5

Calculation of parameters of method correctness

\begin{tabular}{|c|c|c|c|}
\hline \multirow{2}{*}{$\begin{array}{l}\text { Number of solu- } \\
\text { tions }\end{array}$} & \multicolumn{3}{|c|}{ Concentrations of components } \\
\hline & $\begin{array}{l}\text { Introduced in } \% \text { to the concen- } \\
\text { tration of the comparison solu- } \\
\text { tion }\left(C_{i} / C_{s t}\right) * 100 \%\end{array}$ & $\begin{array}{l}\text { Found in } \% \text { to the concentra- } \\
\text { tion of the comparison solu- } \\
\text { tion }\left(\mathrm{S}_{i} / S_{S t}\right) * 100 \%\end{array}$ & $\begin{array}{l}\text { Found in \% to introduced } \\
Z_{i}=\left(\mathrm{S}_{i} / S_{s t}\right) * 100 /\left(C_{i} / C_{s t}\right)\end{array}$ \\
\hline Solution 1 & 80 & 80.20 & 100.25 \\
\hline Solution 2 & 85 & 85.20 & 100.23 \\
\hline Solution 3 & 90 & 90.07 & 100.07 \\
\hline Solution 4 & 95 & 95.32 & 100.33 \\
\hline Solution 5 & 100 & 99.68 & 99.68 \\
\hline Solution 6 & 105 & 104.70 & 99.72 \\
\hline Solution 7 & 110 & 109.61 & 99.65 \\
\hline Solution 8 & 115 & 114.95 & 99.95 \\
\hline Solution 9 & 120 & 119.72 & 99.77 \\
\hline \multicolumn{3}{|c|}{ average $\mathrm{Z}, \%$} & 99.96 \\
\hline \multicolumn{3}{|c|}{ relative standard deviation, $\mathrm{Sz} \%$} & 0.27 \\
\hline \multicolumn{3}{|c|}{ relative confidence interval $\Delta \mathrm{Z}=\mathrm{t}(95 \%, 8) * \mathrm{~s}_{\mathrm{z}}=1.8595 * \mathrm{~s}_{\mathrm{z}}$} & 0.50 \\
\hline \multicolumn{3}{|c|}{ critical for convergence of results $\Delta \% \leq$} & 1.6 \\
\hline \multicolumn{3}{|c|}{ systematic error $\delta \%=\left|Z_{a v}-100\right|$} & 0.04 \\
\hline \multirow{2}{*}{\multicolumn{3}{|c|}{$\begin{array}{l}\text { Criterion of statistical insignificance } \\
\delta \% \leq \Delta Z / 3=0.50 / 3=0.16(0,07 \leq 0,16) ; \\
\text { If not met, the criterion of practical insignificance, } \\
\delta \% \leq 0.512(0.04 \leq 0.512)\end{array}$}} & Executed \\
\hline & & & Executed \\
\hline \multicolumn{3}{|c|}{ General conclusion about the method } & Correct \\
\hline
\end{tabular}

Table 6

The results of the assessment of correctness by two criteria

\begin{tabular}{|c|c|c|c|c|}
\hline Parameter & Value & $\begin{array}{c}\text { Requirements for statistical } \\
\text { insignificance }\end{array}$ & $\begin{array}{c}\text { Requirements for practical } \\
\text { insignificance }\end{array}$ & Fulfillment of the criterion \\
\hline$|\bar{Z}-100|$ & 0.04 & $\leq 0.16$ & $\leq 0.512$ & $\begin{array}{c}\text { Executed according to two } \\
\text { criteria }\end{array}$ \\
\hline
\end{tabular}

Table 7

Determination of parameters of intralaboratory precision

\begin{tabular}{|c|c|c|}
\hline No. & Analyst No. 1 & Analyst No. 2 \\
\hline 1 & 99.87 & 99.72 \\
\hline 2 & 99.44 & 99.11 \\
\hline 3 & 99.34 & 99.50 \\
\hline 4 & 99.37 & 99.48 \\
\hline 5 & 99.38 & 99.59 \\
\hline 6 & 99.36 & 99.13 \\
\hline Mean & 99.46 & 0.105 \\
\hline Dispersion, ${ }^{2}$ & 0.068 & 99.45 \\
\hline \multicolumn{2}{|c|}{ Relative standard deviation, RSD \% } & 0.21 \\
\hline Confidence interval, (Dintra=t(95 \%, m*n-1)* RSD, \%=1,7956 *RSD, \% & 0.42 \\
\hline
\end{tabular}

Table 8

The results of the assessment of intra-laboratory precision

\begin{tabular}{|c|c|c|c|}
\hline Parameter & Criteria requirements & The obtained value & Fulfillment of the criterion \\
\hline$\Delta$ intra & $\leq 1.6$ & 0.42 & Executed \\
\hline
\end{tabular}

Determination of the stability of Epimidin solution

\begin{tabular}{|c|c|c|c|}
\hline Solution & $\begin{array}{c}\text { The average S value of the } \\
\text { peak of the freshly prepared } \\
\text { solution }\end{array}$ & $\begin{array}{c}\text { The average value of the S } \\
\text { peak of the solution after } \\
24 \text { hours }\end{array}$ & $\begin{array}{c}\text { Parameter changes, as a } \\
\text { percentage after 24 hours }\end{array}$ \\
\hline Standard & 1564919 & 1558997 & 0.38 \\
\hline Test & 1513057 & 1508408 & 0.31 \\
\hline
\end{tabular}




\section{Discussion}

The proposed method allows you to reliably and confidently identify and quantify Epimidin. The complete uncertainty of the analysis method $\triangle \mathrm{AS} \%$ less than $\max \Delta \mathrm{AS}(1.48 \%<\max \Delta \mathrm{AS}=1.6 \%$;) is calculated, which meets the requirements for this parameter [17]. Therefore, the uncertainty of sample preparation and analysis in general should provide sufficient measurement accuracy. The developed method of quantitative determination of Epimidin meets the requirements of "System suitability test criteria for chromatographic methods" in terms of parameters: the efficiency of the chromatographic column, the coefficient of separation of peaks on the chromatogram, the rate of peak asymmetry. It is established that all validation parameters meet the necessary eligibility criteria [17]. The specificity of the technique was confirmed by comparing the chromatograms of the comparison solution, the test solution and the chromatogram of the blank solution (solvent). No peaks were found on the blank chromatogram, the retention time of which would coincide with the retention time of the peak of the test compound. Comparison of chromatograms shows that in the conditions of the method, the determination is not hindered by either the solvent or the mobile phase, which indicates the specificity of the method. The method of quantification should be linear within the range of application, which should overlap the possible values of the concentrations of the active substance. SPhU sets the range of application of methods for quantification of $80-120 \%$. Requirements for the linearity of the method were performed over the entire concentration range for Epimidin, and the correlation coefficient was 0.9998. The correctness of the method was performed according to practical and statistical insignificance. The results of the assessment of intra-laboratory precision showed the compliance of the obtained values of the confidence interval of the average result of the acceptability criterion $(\Delta \%=0,42 \leq 1.60)$. The differences between the obtained values of the peak areas should not exceed the criterion of insignificance compared to the maximum allowable uncertainty of the analysis results ( $\triangle \mathrm{AS}$, insig), i.e. $0.512 \%$. According to the results of the determination, it is established that for optimal chromatography conditions it is necessary to use a freshly prepared comparison solution within 24 hours.

Study limitations. In the course of our study, there were difficulties in selecting the optimal chromatography conditions due to the poor solubility of the test substance in most organic solvents and insolubility in water.

Prospects for further research. The proposed technique can be used in the process of pharmaceutical development and standardization of the dosage form.

\section{Conclusions}

An analytical method for the quantitative determination of Epimidin - API with pronounced anticonvulsant activity has been developed. Chromatographic analysis (HPLC) conditions are standardized according to the requirements of $\mathrm{SPhU}$. The requirements for the test "System suitability test criteria for chromatographic methods" are set. Statistical processing of the experimental results shows that the complete uncertainty of the average result is within acceptable limits. For the method of quantitative determination of Epimidin, such validation parameters as specificity, linearity, accuracy, precision and robustness were studied.

\section{Conflict of interests}

There are no conflicts of interest regarding this study.

\section{References}

1. Vogt, V. L., Äikiä, M., del Barrio, A., Boon, P., Borbély, C., Bran, E. et. al. (2017). Current standards of neuropsychological assessment in epilepsy surgery centers across Europe. Epilepsia, 58 (3), 343-355. doi: http://doi.org/10.1111/epi.13646

2. Janmohamed, M., Brodie, M. J., Kwan, P. (2020). Pharmacoresistance - Epidemiology, mechanisms, and impact on epilepsy treatment. Neuropharmacology, 168, 107790. doi: http://doi.org/10.1016/j.neuropharm.2019.107790

3. Severina, A. I., Kavraiskyi, D. P., Shtrygol, S. Yu., Georgiyants, V. A. (2018). Pat. No. 103378 UA. 5-R-1-Aryl-1,5dihydro-4H-pyrazolo[3,4-d]pyrimidin-4-one with anticonvulsant activity. MPK: A61K 31/50. No. u 2015 06663. declared: 06.07.2015; published: 26.02.2018, No. 4. Available at: http://uapatents.com/7-103378-5-r-1-aril-15-digidro-4n-pirazolo34dpirimidin-4-oniv-shho-viyavlyayut-protisudomnu-aktivnist.html

4. Kavraiskyi, D. P., Shtrygol, S. Yu., Georgiyants, V. A., Severina, A. I. (2016). Screening study of novel pyrazolo[3,4d]pyrimidine-4-one derivatives for anticonvulsant activity. Pharmacology and drug toxicology, 3 (49), 16-27.

5. Kavraiskyi, D. P., Shtrygol, S. Yu., Georgiyants, V. A., Severina, A. I. (2016). Experimental study of new pyrazolo[3,4D]pyrimidine-4-one derivatives for anticonvulsant activity spectrum. ScienceRise: Pharmaceutical Science, 1 (1), 10-17. doi: http://doi.org/10.15587/2519-4852.2016.70528

6. O' Sullivan, J., Blake, K., Berntgen, M., Salmonson, T., Welink, J. (2018). Overview of the European Medicines Agency's Development of Product-Specific Bioequivalence Guidelines. Clinical Pharmacology \& Therapeutics, 104 (3), 539-545. doi: http://doi.org/10.1002/cpt.957

7. Andrade, E. L., Bento, A. F., Cavalli, J., Oliveira, S. K., Schwanke, R. C., Siqueira, J. M. et. al. (2016). Non-clinical studies in the process of new drug development - Part II: Good laboratory practice, metabolism, pharmacokinetics, safety and dose translation to clinical studies. Brazilian Journal of Medical and Biological Research, 49 (12). doi: http://doi.org/10.1590/1414$431 \times 20165646$

8. Liu, L., Ouyang, J., Baeyens, W. R. G. (2008). Separation of purine and pyrimidine bases by ion chromatography with direct conductivity detection. Journal of Chromatography A, 1193 (1-2), 104-108. doi: http://doi.org/10.1016/j.chroma.2008.04.011

9. Metwally, F. H., Abdelkawy, M., Abdelwahab, N. S. (2007). Application of spectrophotometric, densitometric, and HPLC techniques as stability indicating methods for determination of Zaleplon in pharmaceutical preparations. Spectrochimica Acta Part A: Molecular and Biomolecular Spectroscopy, 68 (5), 1220-1230. doi: http://doi.org/10.1016/j.saa.2007.01.024

10. Liu, M., Wang, J., Liu, P. (2016). HPLC method development, validation, and impurity characterization of a potent antitumor nucleoside, T-dCyd (NSC 764276). Journal of Pharmaceutical and Biomedical Analysis, 131, 429-435. doi: http://doi.org/10.1016/j.jpba.2016.08.034 
11. Gunnar, T., Ariniemi, K., Lillsunde, P. (2006). Fast gas chromatography-negative-ion chemical ionization mass spectrometry with microscale volume sample preparation for the determination of benzodiazepines and $\alpha$-hydroxy metabolites, zaleplon and zopiclone in whole blood. Journal of Mass Spectrometry, 41 (6), 741-754. doi: http://doi.org/10.1002/jms.1030

12. Larenas, G., Bollo, S., Rodriguez, M., Lemus, I., Nuñez-Vergara, L. J., Squella, J. A., Álvarez-Lueje, A. (2005). Voltammetric Behavior of Zaleplon and Its Differential Pulse Polarographic Determination in Capsules. Journal of AOAC International, 88 (4), 1135-1141. doi: http://doi.org/10.1093/jaoac/88.4.1135

13. Darwish, H. W., Bakheit, A. H., Darwish, I. A. (2016). Enhanced spectrofluorimetric determination of the multitargeted tyrosine kinase inhibitor, crizotinib, in human plasma via micelle-mediated approach. Tropical Journal of Pharmaceutical Research, 15 (10), 2209-2217. doi: http://doi.org/10.4314/tjpr.v15i10.20

14. Satyanarayana, L., Naidu, S. V., Narasimha Rao, M., Suma Latha, R. (2011). The estimation of Nilotinib in capsule dosage form by RP-HPLC. Asian Journal of Pharmaceutical Analysis, 1 (4), 100-102.

15. Swathi, P., Dutt, K. R., Rao, K. N. V., Raja, M. A. (2017). RP-HPLC Method Development and Validation for Estimation of Sofosbuvir in Pure and Tablet Dosage Form. Asian Journal of Pharmacy and Technology, 7 (3), 153-156. doi: http://doi.org/10.5958/2231-5713.2017.00025.3

16. Zhang, B., Zhang, Z., Tian, Y., Xu, F., Chen, Y. (2006). High-performance liquid chromatography-atmospheric pressure chemical ionisation-mass spectrometry determination of zaleplon in human plasma. Journal of Pharmaceutical and Biomedical Analysis, 40 (3), 707-714. doi: http://doi.org/10.1016/j.jpba.2005.06.031

17. Giroud, C., Augsburger, M., Menetrey, A., Mangin, P. (2003). Determination of zaleplon and zolpidem by liquid chromatography-turbo-ionspray mass spectrometry: application to forensic cases. Journal of Chromatography B, 789 (1), 131-138. doi: http://doi.org/10.1016/s1570-0232(03)00135-1

18. Kintz, P., Villain, M., Concheiro, M., Cirimele, V. (2005). Screening and confirmatory method for benzodiazepines and hypnotics in oral fluid by LC-MS/MS. Forensic Science International, 150 (2-3), 213-220. doi: http://doi.org/10.1016/j.forsciint.2004.12.040

19. Foda, N. H., Abd Elbary, A., El- Gazayerly, O. (2006). Reversed-Phase Liquid Chromatographic Determination of Zaleplon in Human Plasma and its Pharmacokinetic Application. Analytical Letters, 39 (9), 1891-1905. doi: http://doi.org/10.1080/00032710600721654

20. Derzhavna Pharmakopeya Ukrayini. Vol. 1. DP «Naukovo-ekspertniy farmakopeyniy tsentr» (2015). Kharkiv: DP «Ukrayinskiy naukoviy farmakopeyniy tsentr yakostI lIkarskih zasobIv», 1128.

Received date 01.06.2020

Accepted date 19.06.2020

Published date 30.06.2020

Hanna Severina, PhD, Associate Professor, Department of Pharmaceutical Chemistry, National University of Pharmacy, Pushkinska str., 53, Kharkiv, Ukraine, 61002

E-mail: severina.ai@ukr.net

Ivan Bezruk, Postgtaduate Student, Department of Pharmaceutical Chemistry, National University of Pharmacy, Pushkinska str., 53, Kharkiv, Ukraine, 61002

E-mail: vania.bezruk@gmail.com

Liudas Ivanauskas, Doctor of Biomedical Sciences, Professor, Head of Department, Department of Analytical and Toxicological Chemistry, Lithuanian University of Health Sciences, Mickevičiaus g. 9, Kaunas, Lithuania, LT 44307

E-mail: liudas.ivanauskas@1smuni.lt

Victoriya Georgiyants, Doctor of Pharmaceutical Sciences, Professor, Head of Department, Department of Pharmaceutical Chemistry, National University of Pharmacy, Pushkinska str., 53, Kharkiv, Ukraine, 61002 E-mail: vgeor@ukr.net 